\title{
Lichen-Associated Bacterium, a Novel Bioresource of Polyhydroxyalkanoate (PHA) Production and Simultaneous Degradation of Naphthalene and Anthracene ${ }^{\mathbb{S}}$
}

\author{
Shamsun Nahar ${ }^{1,3}$, Min-Hye Jeong ${ }^{2}$, and Jae-Seoun Hur $^{2 *}$ \\ ${ }^{1}$ Department of Environmental Education and Science, Sunchon National University, Suncheon 57922, Republic of Korea \\ ${ }^{2}$ Korean Lichen Research Institute, Sunchon National University, Suncheon, Republic of Korea \\ ${ }^{3}$ Department of Food Science and Technology, Chung-Ang University, Anseong 17546, Republic of Korea
}

\author{
Received: August 20, 2018 \\ Revised: November 12, 2018 \\ Accepted: November 12, 2018 \\ First published online \\ November 12, 2018 \\ *Corresponding author \\ Phone: +617503383; \\ Fax: +617503383; \\ E-mail: jshur1@sunchon.ac.kr
}

S upplementary data for this paper are available on-line only at http://jmb.or.kr.

pISSN 1017-7825, eISSN 1738-8872

Copyright(C) 2019 by

The Korean Society for Microbiology and Biotechnology
Lichens are generally known as self-sufficient, symbiotic life-forms between fungi and algae/ cyanobacteria, and they also provide shelter for a wide range of beneficial bacteria. Currently, bacterial-derived biodegradable polyhydroxyalkanoate (PHA) is grabbing the attention of many researchers as a promising alternative to non-degradable plastics. This study was conducted to develop a new method of PHA production using unexplored lichen-associated bacteria, which can simultaneously degrade two ubiquitous industrial toxins, anthracene and naphthalene. Here, 49 lichen-associated bacteria were isolated and tested for PHA synthesis. During the GC-MS analysis, a potential strain of EL19 was found to be a 3-hydroxyhexanoate (3-HHx) accumulator and identified as Pseudomonas sp. based on the 16S rRNA sequencing. GC analysis revealed that EL19 was capable of accumulating 30.62\% and $19.63 \%$ of $3-\mathrm{HHx}$ from naphthalene and anthracene, respectively, resulting in significant degradation of $98 \%$ and $96 \%$ of naphthalene and anthracene, respectively, within seven days. Moreover, the highly expressed $p h a \mathrm{C}$ gene verified the genetic basis of $\mathrm{PHA}_{\mathrm{mcl}}$ production under nitrogen starvation conditions. Thus, this study strongly supports the hypothesis that lichen-associated bacteria can detoxify naphthalene and anthracene, store energy for extreme conditions, and probably help the associated lichen to live in extreme conditions. So far, this is the first investigation of lichen-associated bacteria that might utilize harmful toxins as feasible supplements and convert anthracene and naphthalene into eco-friendly 3-HHx. Implementation of the developed method would reduce the production cost of $\mathrm{PHA}_{\mathrm{mcl}}$ while removing harmful waste products from the environment.

Keywords: Biodegradation, biopolymers, bioproducts, hazardous waste, Pseudomonas

\section{Introduction}

Lichens are generally known as self-sufficient, symbiotic life-forms between fungi and algae/cyanobacteria [1, 2]. In hostile environmental conditions, lichen thalli also serve as a sanctuary for a wide range of bacteria including Azotobacter, Pseudomonas, Beijerinckia, Bacillus, Clostridium, Paenibacillus, Actinomycetes, and Burkholderia among others [3-7]. Bacteria associated with lichens offer several physiological benefits to the lichen. Moreover, lichen holds a very unique biochemical relationship with its partners, a fact that has sparked an interest in many researchers to study these functions in detail. Grube et al. [8] proved that these bacteria are involved in supplying nutrients, degrading the older lichen parts, synthesizing vitamins and hormones, providing protection from toxicities, and so on. However, the bacterial diversity, stress tolerance and adaptive mechanisms, as well as their biochemical and physiological mechanisms still need to be discovered.

Moreover, synthetic plastics/polymers have become an 
integral part of daily life because of their stable, durable, and suitable mechanical and thermal properties. Currently, approximately 127 million metric tons of synthetic plastic are produced annually throughout the world to meet consumer demand [9]. However, this results in the accumulation of solid wastes that are environmentally harmful and expensive to manage. Biodegradable plastics that degrade naturally in the environment are gaining attention because of their potential to overcome plastic oriented problems. Polyhydroxyalkanoate (PHA) is a biodegradable polyester produced directly in bacteria that has been identified as being valuable for industrial processes because of its potential environmental, electrical, pharmaceutical, cosmetic, and biomedical applications [10]. Depending on carbon monomers, this microbial polymer can be categorized as short-chain-length PHA ( $\mathrm{PHA}_{\mathrm{scl}}, 4-5$ carbons) and mediumchain-length PHA ( $\mathrm{PHA}_{\text {mcl }}$, 6-16 carbons). $\mathrm{PHA}_{\mathrm{scl}}$, 3hydroxybutyrate (3-HB), is crystalline and brittle whereas, those classified as $\mathrm{PHA}_{\text {mcl }}$, such as 3-hydroxyhexanoate (3$\mathrm{HHx}, \mathrm{C}_{6}$ ) and 3-hydroxydecanoate (3-HD, $\mathrm{C}_{10}$ ), are elastomers and rubbers [11]. These $\mathrm{PHA}_{\mathrm{mcl}}$ have promising industrial and biomedical applications because they have better physical properties than PHA $_{\text {scl }}[12,13]$.

Although four to five genera of bacteria are known to be capable of producing this biopolymer [14-16], the cost of using this method of production is four to nine times higher than that of traditional production methods [17]. Previously, PHA $_{\mathrm{mcl}}$ was produced from a wide range of renewable and inexpensive carbon sources such as industrial by-products, waste sludge, BETX (benzene, toluene, ethylbenzene, and xylene) and even polycyclic aromatic hydrocarbons, in short PAHs (naphthalene, phenanthrene, etc.), to reduce costs [18-20]. The ubiquitous components of PAHs are found in the industrial (coke, gas, petroleum, and fuel- and coal-based) areas with particularly high concentrations [21]. The US EPA (Environmental Protection Agency) and ATSDR (the Agency for Toxic Substances and Disease Registry) have identified them as hazardous chemicals for aquatic ecosystems because of their photoinduced toxicities [22]. Microbial degradation of toxins is often a better way of removing these materials than costly physicochemical treatments. Although some studies have investigated the production of PHA using toxins, no studies have explored the amount of toxin degradation/utilization throughout the process. To combine these two microbial activities ( PHA $_{\mathrm{mcl}}$ production and toxin degradation), a bifunctional stress tolerant bacterium is needed.

It is well recognized that lichen is a highly tolerant lifeform. Microorganisms present in the lichen are also well adapted to various stressful conditions as well as supporting the lichen in several ways. Cernava et al. [23] reported some bacteria with antagonistic potential, bearing genes involved in the biosynthesis of stress-reducing metabolites. Besides the elimination of stress, the lichen-associated microbiomes showed evidence in the detoxification of inorganic and organic matters such as arsenic, copper, and zinc as well as xenobiotic/PAH substances [24, 25]. Moreover, a comprehensive proteomic study on lung lichen Lobaria pulmonaria showed that bacterial enzymes identified from L. pulmonaria are responsible for the metabolism of methanol/C1compounds and CO-detoxification [26]. On the other hand, it has been strongly believed that PHA synthesis is one of the survival mechanisms of the bacteria to live in stressful and unstable environments [27]. For example, Pham et al. [28] found that PHA production by Pseudomonas aeruginosa plays a very important role in biofilm formation, a surfacedependent complex bacterial aggression. Thus, a connection among lichen-associated bacteria, their tolerance against PAHs, and PHA production was assumed. Therefore, the present study focused on the stress tolerant mechanism of lichen-associated bacteria and enlightened a new source of $\mathrm{PHA}_{\mathrm{mc}}$ production for the first time. To this end, bacteria were isolated from a range of lichen thalli. Two common PAHs, naphthalene and anthracene, were used for the study. The effects of nitrogen concentration on $\mathrm{PHA}_{\mathrm{mcl}}$ accumulation in lichen-associated bacteria were recorded. The detoxification/degradation of naphthalene and anthracene was also determined and evaluated in a time frame manner. Finally, the $\mathrm{PHA}_{\mathrm{mcl}}$ synthase-encoding gene with the expression was also verified.

\section{Materials and Methods}

\section{Lichen Collection and Isolation of Lichen-Associated Bacteria}

Identified lichen samples were kindly provided by the Korean Lichen Research Institute (KoLRI), Sunchon National University, Korea for this study. Lichen samples were collected from several arid areas in Xining Shi, Qinghai Sheng, China $\left(37^{\circ} 20^{\prime} 16.8^{\prime \prime} \mathrm{N}\right.$, $\left.101^{\circ} 23^{\prime} 53.1^{\prime \prime} \mathrm{E}\right)$. Forty lichen samples of twenty-one different species were used in the present study. Lichen samples were washed thrice with sterile $0.85 \% \mathrm{NaCl}$ solution before bacterial isolation. Aseptically ground lichen thalli were spread on nutrient agar (Difco, USA) plates at $22^{\circ} \mathrm{C}$ for bacterial growth. All observed single colonies were then purified by repeated streaking for isolation on nutrient agar plates.

\section{Growth Media and Conditions for Initial Screening}

The purified lichen-associated bacteria were screened for PHA production by subjecting the organisms to feast and famine 
growth conditions. Isolates were first grown in nutrient broth (Difco) for $72 \mathrm{~h}$ to generate a large number of cells, after which they were transferred to nutrient-limited media $\left(6.0 \mathrm{~g} \mathrm{Na}_{2} \mathrm{HPO}_{4}\right.$, $3.0 \mathrm{~g} \mathrm{KH}_{2} \mathrm{PO}_{4}, 0.5 \mathrm{~g} \mathrm{NaCl}, 1.0 \mathrm{mM} \mathrm{MgSO}_{4}$, and $0.1 \mathrm{mM} \mathrm{CaCl}_{2}$ per liter) at $22^{\circ} \mathrm{C}$ and $180 \mathrm{rpm}$ for $7 \mathrm{~d}$ [29]. The nutrient-limited media contained no nitrogen source and either glucose $(20 \mathrm{~g} / \mathrm{l})$, naphthalene $(200 \mathrm{mg} / \mathrm{l})$, or anthracene $(200 \mathrm{mg} / \mathrm{l})$ as the carbon source to induce production of PHA in bacterial cells under stressful conditions. Similar glucose concentration also has been considered in previous studies [30,31]. Dimethyl sulfoxide (DMSO) was used to prepare a stock solution of naphthalene and anthracene. All steps were conducted aseptically in triplicate. All chemicals used in the procedure were purchased from SigmaAldrich Co. (USA).

\section{Initial Screening of Isolates by Nile Blue A}

Initially, the PHA accumulation in the cells under famine conditions was detected by staining as described by Ostle and Holt [32]. Briefly, heat-fixed thin smears of the cells on glass slides were stained with $1 \%$ Nile blue A solution and observed under a Nikon Eclipse Ti microscope (Nikon Instech Co., Ltd., Japan) for the presence of fluorescent PHA granules in the cells.

\section{Final Screening through Gas Chromatography-Mass Spectrometry (GC-MS)}

The GC-MS analysis was conducted to detect the type of PHA produced by the fluoresced isolates. Briefly, the cells that generated PHA were collected by centrifugation at $3,500 \times g$ for $20 \mathrm{~min}$, washed twice with sterile distilled water, and lyophilized through a freeze drier (Hanil Science Industrial Co., Ltd., Korea) for $6 \mathrm{~h}$. The dry cell weight $(\mathrm{DCW})$ represents the total cell biomass generated in each $100 \mathrm{ml}$ of media. The PHA from the dry pellets was extracted through sonication with chloroform $(80 \mathrm{ml} / \mathrm{g}$ of DCW $)$ at $60^{\circ} \mathrm{C}$ for $6 \mathrm{~h}$. The sample was filtered $(0.45 \mu \mathrm{l}$ syringe filters $)$ and methanolized by using equal volumes of acidified methanol solution $\left(15 \%\right.$ [v/v $\left.\mathrm{H}_{2} \mathrm{SO}_{4}\right)$ and chloroform at $100^{\circ} \mathrm{C}$ for $2 \mathrm{~h}$ [33]. The chemicals used were purchased from Sigma-Aldrich Co. (USA).

The PHA composition of the methanolized samples was evaluated using a GC-2010 gas chromatograph coupled with a QP2010 mass spectrometer (Shimadzu, Japan) and a Rtx-5MS capillary column $(30 \mathrm{~m} \times 0.25 \mathrm{~mm} \times 0.25 \mu \mathrm{m})$. For each analysis, $1 \mu \mathrm{l}$ of sample was injected in split mode (1:50). The temperature gradient program followed that described by Dib et al. [34]. An MS detector using electron ionization (EI) at $70 \mathrm{eV}$ was operated and EI mass spectra were acquired within a range of $\mathrm{m} / \mathrm{z} 35-$ $350 \mathrm{da}$. The target compounds were identified using the National Institute of Standards and Technology (NSIT02) database with their chemical formula, molecular weight, and NIST number.

\section{Identification and Phylogenetic Analysis of the Bacteria Based on 16S rRNA Sequencing}

Fresh cultures of interest were identified by PCR amplification of the 16S rRNA region of the strains. The DNA of the isolates were extracted using a G-spin DNA extraction kit (iNtRON Biotechnology, Korea) to amplify them with $20 \mu \mathrm{l}$ of Accupower PCR premix (Bioneer, Korea) and the universal primer set, 27F/ $1492 \mathrm{R}$ with the thermal conditions of $95^{\circ} \mathrm{C}$ for $5 \mathrm{~min}$, followed by 25 cycles of $95^{\circ} \mathrm{C}$ for $1 \mathrm{~min}, 55^{\circ} \mathrm{C}$ for $1 \mathrm{~min}$, and $72^{\circ} \mathrm{C}$ for $30 \mathrm{sec}$ and then final extension at $72^{\circ} \mathrm{C}$ for $10 \mathrm{~min}$ [35]. Amplification was confirmed by electrophoresis on $1 \%$ agarose gel. PCR product was sequenced, and the generated sequence was aligned with the related strains obtained from the EzTaxon-e server (http:// eztaxon-e.ezbiocloud.net/) [36] using the Clustal_X program [37]. The obtained sequence was deposited in the NCBI database under the accession number KX442588. Phylogenetic analysis was carried out by neighbor-joining [38] method using Molecular Evolutionary Genetics Analysis software (MEGA7) [39]. Bootstrap analysis was performed based on 1000 replicates for the evaluation of tree topology.

\section{Evaluation of Nitrogen Concentration with Other Environmental Conditions for Optimum PHA $_{\mathrm{mcl}}$ Production}

The nitrogen concentration of the nutrient-limited media was evaluated using different amounts of $\mathrm{NH}_{4} \mathrm{Cl}$. For this study, the cells were first grown in nutrient broth, then transferred to nutrient-limited media containing $0 \mathrm{~g}, 0.25 \mathrm{~g}, 0.50 \mathrm{~g}$, and $1.0 \mathrm{~g} / \mathrm{l}$ of $\mathrm{NH}_{4} \mathrm{Cl}$ with $200 \mathrm{mg} / \mathrm{l}$ of naphthalene. The samples were collected after five days of incubation at $22^{\circ} \mathrm{C}$ with $180 \mathrm{rpm}$ and then prepared as described above for GC analysis. The monomer concentration was determined by comparison to the abundance peak of the standard and groups were compared by one-way ANOVA with Tukey's multiple test correction.

The optimum carbon concentration, temperature, and $\mathrm{pH}$ were determined for the $\mathrm{PHA}_{\text {mcl }}$ producing bacteria. Naphthalene and anthracene were added to nutrient-limited media at different concentrations $(200,400,600,800,1,400$, and $1,600 \mathrm{mg} / \mathrm{l})$ to evaluate the tolerance of the strains at $22^{\circ} \mathrm{C}$ for $5 \mathrm{~d}$. The optical density (OD) of the strains was determined by UV spectrometry (Optizen 3220UV, Mecasys, Korea). The optimum temperature and $\mathrm{pH}$ of the strains were determined based on the OD observed after cultivating the organisms at seven different temperatures $\left(5^{\circ} \mathrm{C}, 15^{\circ} \mathrm{C}, 20^{\circ} \mathrm{C}, 25^{\circ} \mathrm{C}, 30^{\circ} \mathrm{C}, 37^{\circ} \mathrm{C}\right.$, and $\left.40^{\circ} \mathrm{C}\right)$ and five different $\mathrm{pHs}(5,6,7,8$, and 9) in nutrient broth media for $24 \mathrm{~h}$.

\section{Yield Determination of the PHA $_{\mathrm{mcl}}$ Monomer}

To determine the total yield, either naphthalene or anthracene was used for $7 \mathrm{~d}$ of famine stage culture. Additionally, glucose was used to compare the growth and $\mathrm{PHA}_{\text {mcl }}$ production. Samples and standards were prepared in the same manner as described above. Gas chromatography (GC) was conducted using an Agilent 7890A GC system equipped with an HP-20M capillary column $(30 \mathrm{~m} \times 0.25 \mathrm{~mm} \times 0.25 \mu \mathrm{m})$ and a FID detector. GC conditions were maintained according to a procedure adapted from Goh and Tan [29]. The monomer was detected by comparison with a standard. 


\section{Analysis of Xenobiotic Degradation}

The degradation patterns of naphthalene and anthracene were analyzed using GC-MS analysis. During sample preparation, the bacterial pellets were removed through repeated centrifugation (3,800 $\times g$ for $20 \mathrm{~min})$. The collected liquid part was sonicated (at $45^{\circ} \mathrm{C}$ for $\left.90 \mathrm{~min}\right)$ using an equal volume $(1: 1, \mathrm{v} / \mathrm{v})$ of n-hexane and the polar fraction was then collected. The filtered samples were analyzed by GC-MS while increasing the oven temperature from $60^{\circ} \mathrm{C}$ to $290^{\circ} \mathrm{C}$ at $6^{\circ} \mathrm{C}$ per min, after which the temperature was held at $290^{\circ} \mathrm{C}$ for $12 \mathrm{~min}$. The sample was injected in split mode (1:30) with a purge flow rate of $3 \mathrm{ml} / \mathrm{min}^{-1}$. The retention time (RT) and $m / z$ of anthracene and naphthalene were determined using pure compounds (Sigma-Aldrich Co., USA). The percent of degraded xenobiotics was measured based on comparison with the absorbance area of the control. Acquired data were analyzed by one-way ANOVA with Tukey's multiple test correction.

\section{Verification of the $\mathrm{PHA}_{\mathrm{mcl}}$ Synthase-Encoding Gene}

Amplification of the $\mathrm{PHA}_{\text {mcl }}$ synthase-encoding gene ( $\mathrm{haC}$ ) fragment from the conserved region of the sample genomic DNA was conducted using the specific primer set, I-179L (5'-ACA GAT CAA CAA GTT CTA CAT CTT CGA C -3')/ I-179R (5'-GGT GTT GTC GTT GTT CCA GTA GAG GAT GTC - $3^{\prime}$ ) [40]. The procedure consisted of DNA denaturation at $94^{\circ} \mathrm{C}$ for 5 min followed by 30 cycles of amplification $\left(30 \mathrm{sec}\right.$ at $94^{\circ} \mathrm{C}, 30 \mathrm{sec}$ at $55^{\circ} \mathrm{C}, 1 \mathrm{~min} 30 \mathrm{sec}$ at $72^{\circ} \mathrm{C}$ ), after which the samples were subjected to a final extension at $72^{\circ} \mathrm{C}$ for $5 \mathrm{~min}$. Amplified products were confirmed by electrophoresis in $1 \%$ agarose gel. The sequences were then used for BLAST searches of the NCBI database. The obtained sequence of phaC fragment was deposited in the NCBI database under accession numbers KY645972.

\section{Expression Analysis of the PHA $_{\text {mcl }}$ Synthase-Encoding Gene}

To analyze the expression of $p h a C$ gene in vitro, bacteria were cultured in nutrient broth and then transferred to nutrient-limited media containing glucose $(20 \mathrm{~g} / \mathrm{l})$, naphthalene $(200 \mathrm{mg} / \mathrm{l})$, or anthracene $(200 \mathrm{mg} / \mathrm{l})$ as described before. Bacteria were collected after 3 days of growth in triplicates for RNA extraction. Total
Table 1. Sequences of the primers used for Real-time PCR.

\begin{tabular}{ll}
\hline \multicolumn{1}{c}{ Primer } & \multicolumn{1}{c}{ Nucleotide sequence (5' to $3^{\prime}$ ) } \\
\hline rpoS-F & CTCCCCGGGCAACTCCAAAAG \\
rpoS-R & CGATCATCCGCTTCCGACCAG \\
EL19_phaC-F & GACAGCCAGATCGACAGC \\
EL19_phaC-R & GTAGTTCCAGATCAGGTCGTTG \\
\hline
\end{tabular}

RNA of the sample was collected by using easy-spin Total RNA Extraction Kit (iNtRON Bio Technology, Korea) according to the manufacturer's instructions. The reverse transcription of mRNA to cDNA was performed using an ImProm-II Reverse Transcription System (Promega, USA) as stated in the manufacturer's protocol. Reactions were performed in a $10-\mu l$ volume containing $100 \mathrm{nM}$ of each primer, $2 \mu \mathrm{l}$ of cDNA (12.5 ng of input RNA) and $5 \mu \mathrm{l}$ of iTaqTM Universal SYBR green one-step kit (Bio-Rad, USA). The primers used for this study were shown in Table 1. Real-time PCR was run on CFX96 real-time PCR detection system (Bio-Rad Laboratories). Normalization and comparison of mean threshold cycle $\left(C_{t}\right)$ values were analyzed as described previously by Livak and Schmittgen [41]. To compare the relative abundance of the transcripts of target genes, the $C_{t}$ of triplicate reactions was normalized by that of rpoS gene. Fold changes were compared to controls without anthracene and naphthalene.

\section{Results}

\section{Isolation and Screening of Target Lichen-Associated Bacteria}

A total of 49 lichen-associated bacterial strains were isolated from 40 lichen samples by repeated streaking. Initially, twenty-three Nile blue A-stained isolates were identified based on fluorescence emitted under the UV microscope (Fig. 1). However, only one isolate (EL19) from Xanthoria sp. was found to produce PHA $_{\mathrm{mcl}}$ from naphthalene and anthracene upon final screening. The detected monomer of $\mathrm{PHA}_{\mathrm{mcl}}$ was identified as 3-hydroxyhexanoate

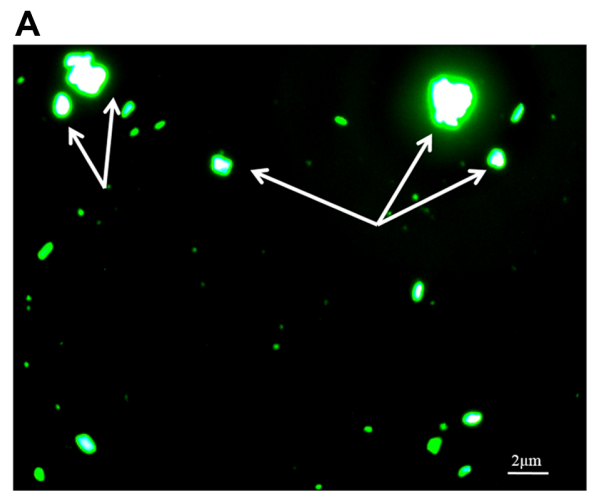

B

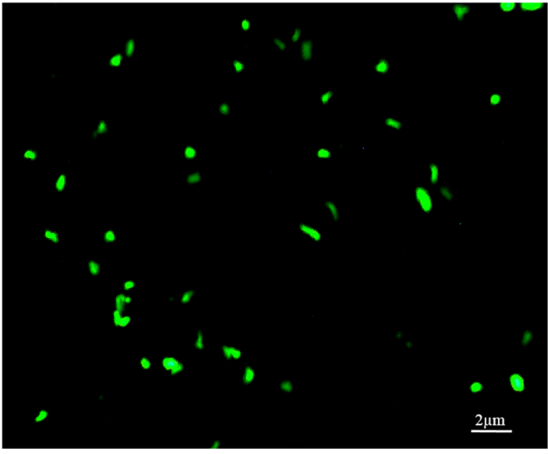

Fig. 1. Lichen-associated isolates under a UV microscope after staining with Nile blue A.

(A) Arrow pointing to the fluorescent PHA granules in the bacterial cell. (B) Bacterial cells with no PHA granules. 


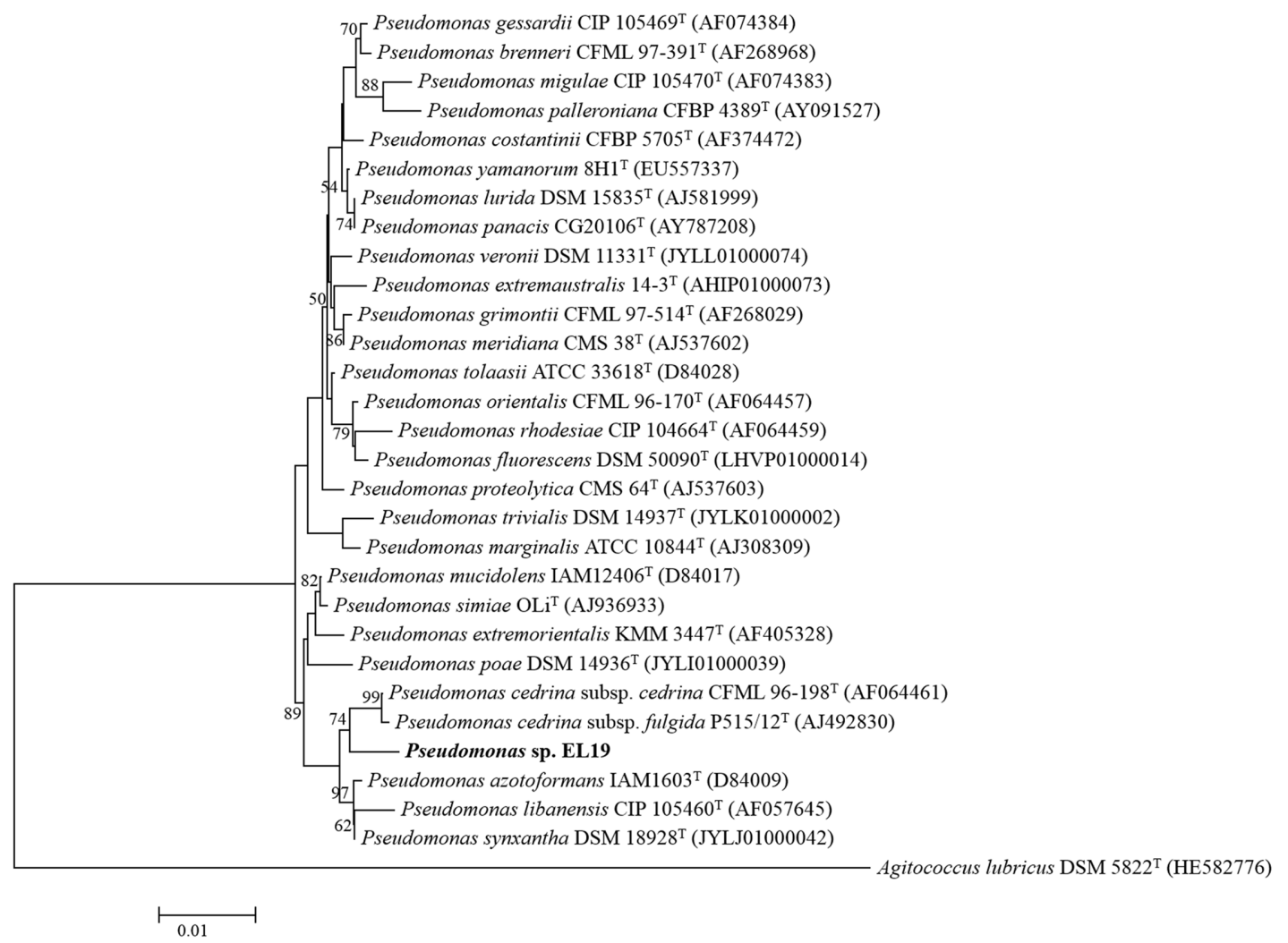

Fig. 2. Neighbor-joining phylogenetic tree of strain Pseudomonas sp. EL19 with all other Pseudomonas species based on the 16S rRNA gene sequences similarities.

Numbers at nodes represent the bootstrap values (based on 1,000 replications) and only $>50 \%$ are shown. Agitococcus lubricus DSM 5822 has been selected from same order in different family and is used as the outgroup. Bar, 0.01 estimated nucleotide substitutions per site.

(3-HHx) by GC-MS analysis (Fig. S1) and further confirmed with the standard by GC analysis. The $\mathrm{PHA}_{\mathrm{mcl}}$-producing bacterium was identified by PCR amplification of the $16 \mathrm{~S}$ rRNA region ( 1,500 bp). A search of the aligned sequences in the EzTaxon database revealed the highest (99.5\%) sequence similarity of the isolate with Pseudomonas azotoformans DSM 18862. Phylogenetic analysis exhibited that the strain formed a strong phyletic lineage with Pseudomonas synxantha DSM 18928, Pseudomonas libanensis CIP 105460, Pseudomonas azotoformans DSM 18862, Pseudomonas cedrina subsp. cedrina CFML 96-198, and Pseudomonas cedrina subsp. fulgida P515/12 within the genus Pseudomonas (Fig. 2). Therefore, the present isolate was further identified as Pseudomonas sp. strain EL19.

\section{Evaluation of Growth Conditions for Maximum PHA mcl Production}

Four different concentrations of $\mathrm{NH}_{4} \mathrm{Cl}(0,0.25,0.50$, and $0.75 \mathrm{~g} / \mathrm{l})$ were used for the analysis. The study revealed that maximum 3-HHx could be produced under higher nitrogen stress. Here, Pseudomonas sp. strain EL19 produced $82.5 \mathrm{mg} / 1$ of 3-HHx with the media containing no nitrogen, followed by $56.8 \mathrm{mg} / \mathrm{l}$. In contrast, the lowest amount of 3$\mathrm{HHx}(35.3 \mathrm{mg} / \mathrm{l})$ was yielded from $0.75 \mathrm{mg} / 1$ of $\mathrm{NH}_{4} \mathrm{Cl}$ after $7 \mathrm{~d}$ of famine condition (Fig. 3A). Moreover, the growth of Pseudomonas sp. strain EL19 was recorded for different concentrations of naphthalene and anthracene by observing the optical densities during incubation. Pseudomonas sp. strain EL19 showed growth with all concentrations of naphthalene, although the growth decreased as concentration increased (Fig. 3B). The strain showed no growth in response to higher concentrations of anthracene (1,400 and 1,600 mg/l) (Fig. 3B). The optimum temperature and $\mathrm{pH}$ for the growth of the Pseudomonas $\mathrm{sp}$. strain EL19 were found to be $20^{\circ} \mathrm{C}-25^{\circ} \mathrm{C}$ and 7 , respectively (Figs. 3C and 3D).

\section{Yield Determination of 3-HHx}

Pseudomonas sp. strain EL19 accumulated 3-HHx from naphthalene and anthracene during seven days of famine 
A

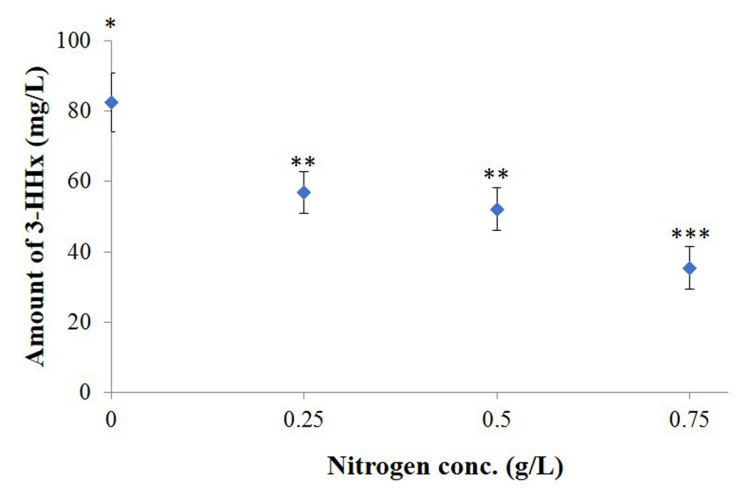

C

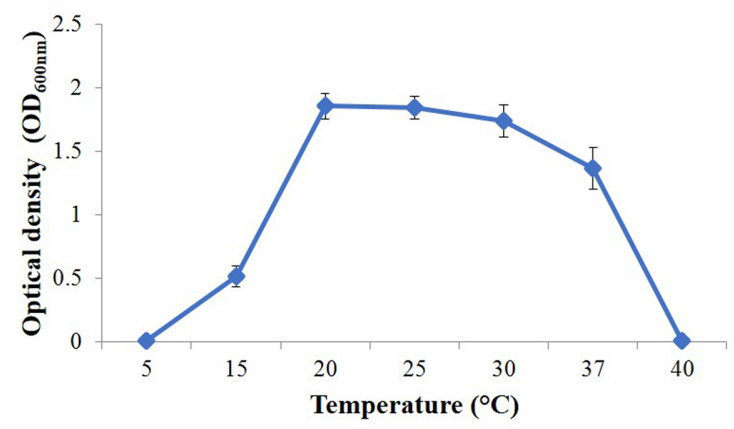

B

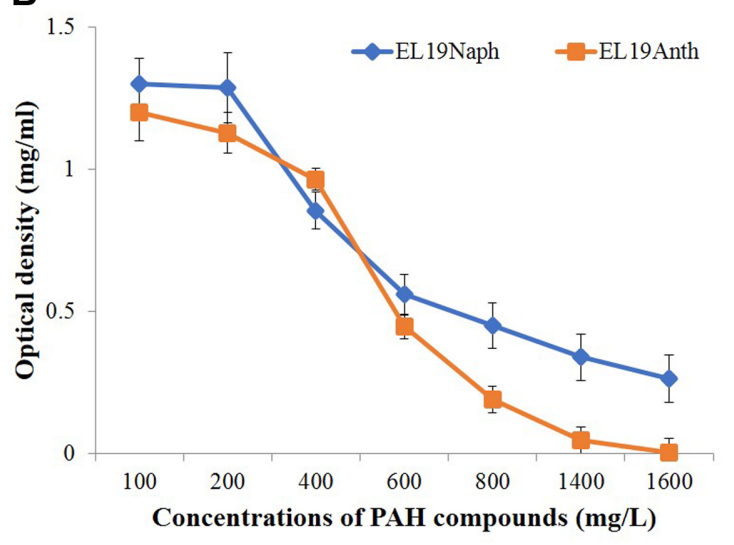

D

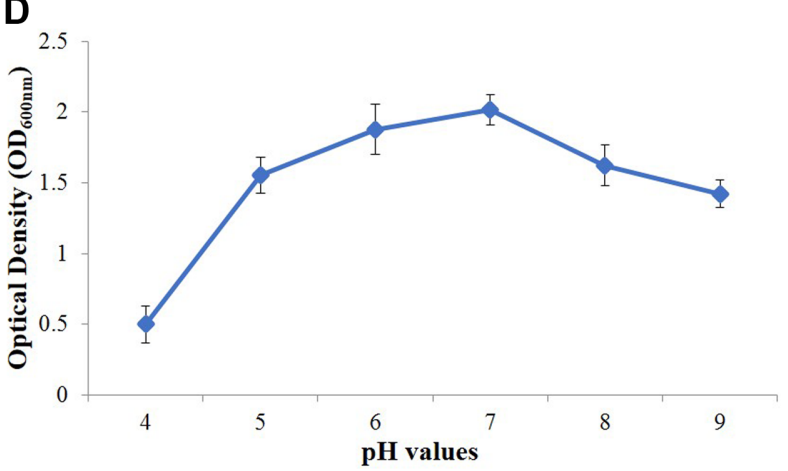

Fig. 3. Different growth conditions of Pseudomonas sp. EL19 during 3-HHx production.

(A) Optimum nitrogen concentration for maximum 3-HHx production. Data are presented as the means \pm SEM (3 replicates). Different symbols ${ }^{*}$, **, $\left.{ }^{* * *}\right)$ indicate significant differences among nitrogen concentrations for the highest 3-HHx production as determined by one-way ANOVA $(p<0.05)$. (B) Bacterial growth at different concentrations of naphthalene (EL19Naph) and anthracene (EL19Anth). (C) Optimum temperature for bacterial growth to produce $\mathrm{PHA}_{\mathrm{mcl}}$. (D) Optimum $\mathrm{pH}$ of the growth medium for $\mathrm{PHA}_{\text {mcl }}$ production.

conditions. The yield of 3-HHx was determined by GC analysis. In case of naphthalene as the carbon substrate, Pseudomonas sp. strain EL19 produced $88.43 \mathrm{mg} / 1$ of 3-HHx which was $30.62 \%$ of total dry cell weight of the bacterium (DCW) (Table 2). The bacterium produced $66.41 \mathrm{mg} / 1$ $(19.63 \%)$ of 3-HHx from $333.66 \mathrm{mg} / 1$ of DCW when

Table 2. Dry cell weight (DCW), amount of 3-HHx recovered and percent production by the lichen-associated bacteria, Pseudomonas sp. EL19.

\begin{tabular}{lccc}
\hline $\begin{array}{c}\text { Carbon } \\
\text { source }\end{array}$ & $\begin{array}{c}\mathrm{DCW} \\
(\mathrm{mg} / \mathrm{l})\end{array}$ & $\begin{array}{c}\text { 3-HHx } \\
\text { recovered } \\
(\mathrm{mg} / \mathrm{l})\end{array}$ & $\begin{array}{c}\text { 3-HHx } \\
\text { production } \\
(\% \mathrm{DCW})\end{array}$ \\
\hline Naphthalene & $293.33 \pm 12.68$ & $88.43 \pm 13.78$ & $30.62 \pm 6.04$ \\
Anthracene & $333.66 \pm 16.49$ & $66.41 \pm 18.29$ & $19.63 \pm 4.62$ \\
Glucose & $696.67 \pm 10.40$ & $\mathrm{ND}$ & $\mathrm{ND}$ \\
\hline
\end{tabular}

*Not detected: ND anthracene was used as sole carbon source (Table 2). Although the maximum growth was achieved, the bacterium was unable to accumulate 3-HHx when glucose was supplied instead of naphthalene or anthracene as the carbon source (Table 2).

\section{Degradation Analysis of Naphthalene and Anthracene}

Significant differences were observed upon GC-MS analysis of the simultaneous degradation of naphthalene and anthracene during 3-HHx production. After five days of deprived condition with naphthalene, Pseudomonas sp. strain EL19 degraded $98.3 \%$ of naphthalene (Fig. 4A). Conversely, the bacterium was able to degrade $75.9 \%$ of anthracene after the fifth day of inoculation. However, Pseudomonas sp. strain EL19 degraded 96.4\% of anthracene within seven days of famine condition (Fig. 4C). Data were compared using a GC-MS data comparison tool for strain EL19 during each day of degradation of naphthalene and 
A

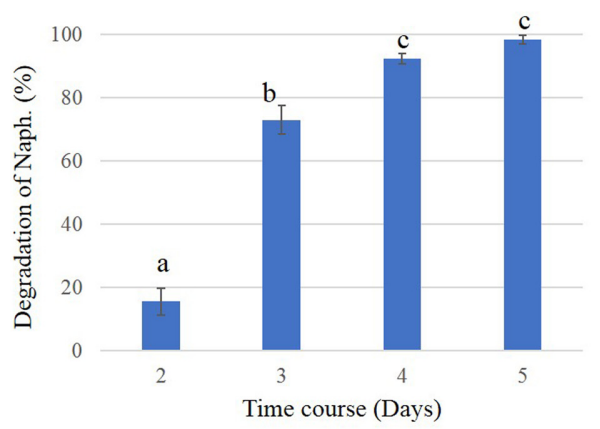

C

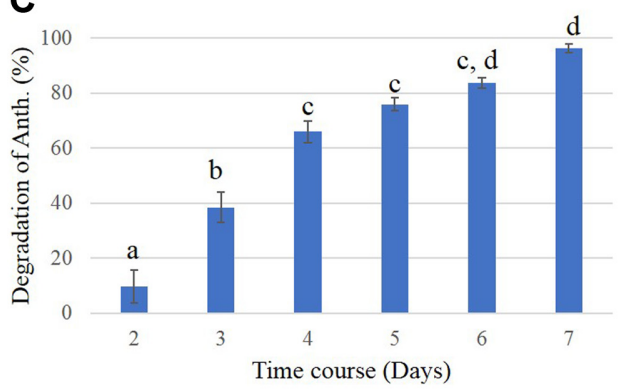

B

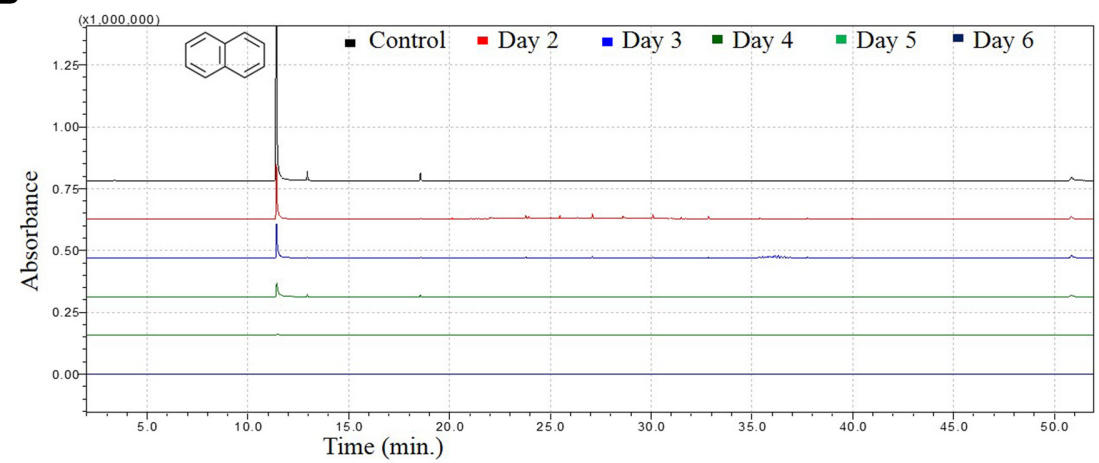

D

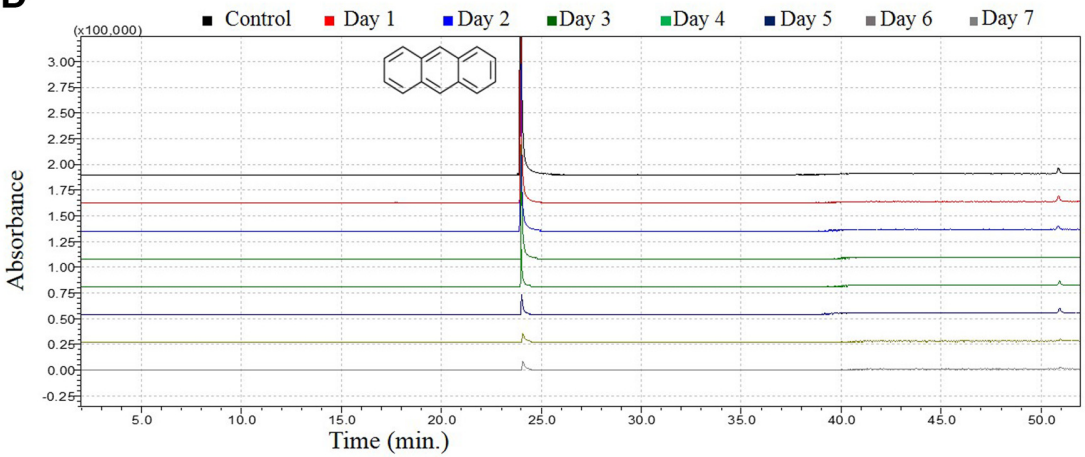

Fig. 4. Degradation of naphthalene and anthracene over time.

(A) Percent (\%) degradation of naphthalene (Naph.) by Pseudomonas sp. EL19 over time. (B) Chromatographs of each day comparing naphthalene degradation by Pseudomonas sp. EL19 to a control. (C) Percent (\%) degradation of anthracene (Anth.) by Pseudomonas sp. EL19 over time. (D) Chromatographs of each day comparing anthracene degradation by Pseudomonas sp. EL19 to a control. Data are presented as the means \pm SEM (three replicates). Values with different characters $(a, b, c, d)$ indicate significant differences in daily degradation of anthracene and naphthalene by the isolates as determined by one-way ANOVA $(p<0.05)$.

anthracene. After the fifth day of incubation of Pseudomonas sp. strain EL19, no naphthalene was detected in the GC chromatograph (Fig. 4B). However, a lower absorbance of anthracene (compare to control) was still detected after the seventh day of incubation of the strain EL19 (Fig. 4D).

\section{Verification and Expression of $\mathrm{PHA}_{\mathrm{mcl}}$ Synthase-Encoding Gene}

The $\mathrm{PHA}_{\mathrm{mcl}}$ synthase-encoding gene $(p h a C)$ from the conserved region was amplified using a specific primer set and the expected $540 \mathrm{bp}$ PCR product was obtained from gel electrophoresis (data not shown). The acquired sequence of the fragment was analyzed and compared with previously published sequences from the NCBI database. The results showed an $88 \%$ similarity with Pseudomonas fluorescens PhhR-like protein and PhaC (phaC) genes. Furthermore, the presence of $p h a C$ was confirmed by analyzing the expression of the gene (in vitro) through qRT-PCR. The relative abundance of the transcripts was

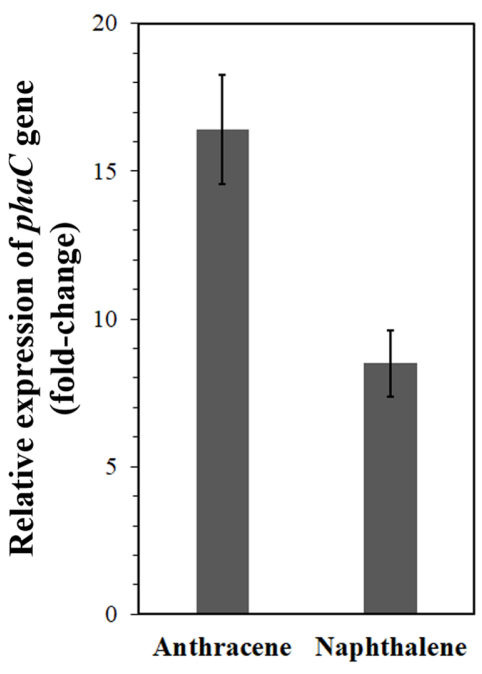

Fig. 5. Expression of $p h a C$ as determined by qRT-PCR.

Values shown representing the expression of phaC normalized against the expression of rpoS. Biological triplicates were assayed using technical replicates. Standard error bars are shown. 
determined with both anthracene and naphthalene. Pseudomonas sp. strain EL19 showed higher expression of phaC with naphthalene than anthracene (Fig. 5). The normalized values for naphthalene and anthracene were 8.5 and16.4, respectively.

\section{Discussion}

Although $\mathrm{PHA}_{\mathrm{mcl}}$ is valuable for plastic industries, producers usually face several obstacles in $\mathrm{PHA}_{\text {mcl }}$ production, including selection of inexpensive carbon sources and suitable host bacteria. The present study was conducted to add several new aspects of research to $\mathrm{PHA}_{\mathrm{mcl}}$ production from naphthalene and anthracene using lichenassociated bacteria. To accomplish this, PHA-producing bacteria were screened with Nile blue A stain followed by GC-MS. Twenty-three isolates showed positive results after staining with Nile blue A. However, only EL19 was found to be a $\mathrm{PHA}_{\mathrm{mcl}}$ generator under stressful conditions by GCMS analysis (Fig. 1). Different results between screening methods might occur because of the ability of lipophilic Nile blue A to stain neutral lipids along with the PHAs [42]. EL19 has been isolated from Xanthoria sp. and identified as a member of the genus Pseudomonas by the neighbor-joining tree topology based on 16S rRNA sequencing. Pseudomonas has been previously isolated from Xanthoria elegans with many other associated bacteria [43]. On the other hand, Pseudomonas, with Stenotrophomonas, Micrococcus, and Burkholderia have been characterized as bio-synthesizers of stress-reducing metabolites in the large epiphytic lichen, Lobaria pulmonaria [44]. Therefore, it can be assumed that the presence of Pseudomonas sp. EL19 in Xanthoria sp. may benefit in carbon storage, detoxification, and stress adaptation, which may help the lichen to live longer [45]. The metaproteome analysis of L. pulmonaria also supports the hypothesis. Eymann et al. [26] established that the functional diversities of the symbionts of L. pulmonaria assist the lichen in longevity.

The optimum nitrogen concentration for maximum production of 3-HHx was determined as bacteria are more likely to produce PHA when they are in stress, particularly under nitrogen-limited conditions [46,47]. The results demonstrated that strain EL19 produced the maximum amount $(82.5 \mathrm{mg} / \mathrm{l})$ of 3-HHx with media containing $0 \mathrm{~g} / 1$ of nitrogen, followed by $0.25 \mathrm{~g} / 1$ of nitrogen (Fig. 3A). Hence, media with no nitrogen was optimal for higher productivity of 3-HHx. Mohan and Reddy [17] optimized critical factors for PHA production from a mixed culture system and found $0.10 \mathrm{~g} / 1$ of ammonium chloride to be the best-suited condition for maximum production. However, Thakor et al. [48] found that $0.20 \mathrm{~g} / 1$ was the optimum concentration of ammonium nitrate for PHB production. Moreover, strain EL19 showed great tolerance to naphthalene in comparison with $P$. fluorescens $26 \mathrm{~K}$ $(600 \mathrm{mg} / \mathrm{l})$, Pseudomonas sp. TN301 (12 mg/l), and Bacillus sp. CYR1 $(100 \mathrm{mg} / \mathrm{l})[19,43,49]$ at $20^{\circ} \mathrm{C}-25^{\circ} \mathrm{C}$ and $\mathrm{pH} 7$ (Fig. 3). Panda et al. [50] found that neutral $\mathrm{pH}$ is also helpful for PHA-producing enzyme activation as well as PHA production. However, Antarctic Pseudomonas sp. UMAB-40 showed the highest growth at $15^{\circ} \mathrm{C}$ when cultured under nitrogen-limited conditions [29].

A number of stress tolerant bacteria were used for $\mathrm{PHA}_{\text {mcl }}$ synthesis from the related carbon substrate [29]. Here, the newly isolated lichen-associated bacteria were used for bioconversion of 3-HHx from two completely unrelated carbon substrates. Monoaromatic and polyaromatic hydrocarbons such as BTEX, styrene, phenol, 4-chlorophenol, naphthalene, and phenanthrene have previously been converted to PHA using Pseudomonad, Aeromonad, and Bacillus bacteria which were mainly comprised of 3-hydroxyhexanoate (3-HHx), 3-hydroxyoctanoate (3-HO), 3-hydroxydecanoate (3-HD), and 3-hydroxydodecanoate (3-HDD) [18, 22, 51]. Interestingly, the lichen-associated bacterium, Pseudomonas sp. strain EL19 was able to accumulate the single homopolymer, 3-HHx when naphthalene and anthracene were used as carbon substrates (Table 2). Typically, 3-HHx is strongly amorphous in nature, giving the polymer a suitable structure for biomedical applications, bio-implantation, and adhesiveness and also making it more useful [52]. Previously, Chung et al. [53], Elbahloul and Steinbüchel [54], and Gao et al. [55] reported 3-HDD and 3-HO production as the single homopolymer for better elastic and biodegradable properties than the highly studied $\mathrm{PHA}_{\text {scl. }}$.

In this study, Pseudomonas sp. strain EL19 showed higher 3 -HHx production $(30.62 \%$ DCW) with naphthalene (Table 2). Similarly, $19.63 \%$ DCW of 3-HHx was generated by strain EL19 from anthracene (Table 2). The total yield of 3-HHx from PAH compounds was higher than that of previous studies. Narancic et al. [19] found that Pseudomonas sp. TN301 produced $23 \% \mathrm{CDW} \mathrm{PHA}_{\mathrm{mcl}}\left(\mathrm{C}_{6}-\mathrm{C}_{12}\right)$ with naphthalene and $3.5 \% \mathrm{CDW}\left(\mathrm{C}_{8}-\mathrm{C}_{12}\right)$ with phenanthrene. Among total PHAs, 4\% 3-HHx $\left(\mathrm{C}_{6}\right)$ was produced by the strain. Reddy et al. [22] reported 18\% PHB production from phenanthrene by Bacillus sp. CYR1, while no PHB was generated by Cupriavidus sp. CY-1 [56]. However, P. putida KT2440 has been shown to produce higher amounts of $\mathrm{PHA}_{\text {mcl }}$ from octanoic acid, nonanoic acid, glucose, acrylic 
acid, potassium octanoate, and potassium 10-undecenoate at levels ranging from 16.2 to $75.5 \%$ DCW [57-59]. In the current study, no $3-\mathrm{HHx}$ was found in the glucosecontaining medium.

Conversely, Pseudomonads are a well-known community of xenobiotic degraders [59, 60]. A number of bacterial isolates including Pseudomonas sp. are known to degrade polyaromatic hydrocarbons; however, very few of these can produce PHA compounds [61-63]. In the present study, we demonstrated that the EL19 strain significantly degraded $98 \%$ of the naphthalene in five days (Fig. 4A) and stored the carbon intracellularly as 3-HHx. Many studies have reported efficient degradation by Pseudomonads. For example, Filonov et al. [21] found that $95 \%$ of naphthalene was degraded by Pseudomonas putida G7 in the soil after $5 \mathrm{~d}$. In batch cultures, P. stutzeri 19SMN4 was found to degrade $93 \%$ of naphthalene in sea-water [64], while $96.1 \%$ of naphthalene was removed by $P$. aeruginosa PTCC 1707 strain [65]. Jacques et al. [66] found that P. aeruginosa 312A, $P$. citronellolis 222A, and $P$. aeruginosa 332C could remove $71 \%, 51 \%$, and $24.4 \%$ of anthracene, respectively. However, these strains are not able to act as bi-functional bacteria as the lichen-associated Pseudomonas sp. strain EL19 with the simultaneous production of 3-HHx.

Additionally, a genomic-confirmation of the $\mathrm{PHA}_{\mathrm{mcl}}{ }^{-}$ producing capability of the strain EL19 had been conducted. The class II PHA synthase-encoded gene ( $p h a C)$ which is responsible for $\mathrm{PHA}_{\mathrm{mcl}}$ synthesis in Pseudomonas sp. and Burkholderia caryophylli [67, 68], was amplified and the expression of phaC (in-vitro) was analyzed by qRT-PCR. Previously, it has been used as a rapid tool for PHAproducing isolate identification [69, 70]. However, the current study focused on the genomic expression detected with both conditions (either naphthalene or anthracene) to verify the function of $p h a C$ gene. The result showed higher expression of phaC gene when naphthalene was used as sole carbon source (Fig. 5). Wang and Nomura [30] analyzed the expression level of PHA synthase gene encoding enzymes (phaC1, phaC2, phaZ, and phaJ4) and found higher expressions when $P$. putida was grown with lauric acid to produce 3-HO, which also agreed with our result. Therefore, it can be assumed that there is a direct correlation with phaC gene encoding enzymes in 3-HHx production by the lichen-associated Pseudomonas sp. EL19 when grown with PAHs.

The current study focused on a novel source of $\mathrm{PHA}_{\mathrm{mcl}}{ }^{-}$ producing bacteria with a complete degradation of $\mathrm{PAH}$ compounds. The study shed light on how to utilize lichenassociated bacteria and their stress tolerant metabolic system to accumulate 3-HHx using naphthalene and anthracene as a carbon source. The results suggest that Pseudomonas sp. EL19 is very efficient in the production of 3-HHx and simultaneous degradation of naphthalene and anthracene under nitrogen stress conditions. The highly expressed phaC gene also suggests correlation to class II PHA synthase enzymes with 3-HHx synthesis. Thus, this study strongly supports the hypothesis that lichen-associated bacteria can detoxify naphthalene and anthracene, store energy for extreme conditions, and probably help the associated lichen in self-defense. So far, this is the first investigation of utilizing lichen-associated bacteria in a bifunctional way. Implementation of the developed method would reduce the production cost of $\mathrm{PHA}_{\mathrm{mcl}}$ while removing harmful waste products from the environment.

\section{Acknowledgment}

This work was supported by grants from the Korea National Research Foundation (NRF-2017R1A2B4011091 and NRF-2017M3A9B806947).

\section{Conflict of Interest}

The authors have no financial conflicts of interest to declare.

\section{References}

1. Grube M, Cardinale M, Jr de Castro JV, Müller H, Berg G. 2009. Species-specific structural and functional diversity of bacterial communities in lichen symbioses. ISME J. 3: 11051115.

2. Bates ST, Cropsey GWG, Caporaso JG, Knight R, Fierer N. 2011. Bacterial communities associated with the lichen symbiosis. Appl. Environ. Microbiol. 77: 1309-1314.

3. Iskina RY. 1938. On nitrogen fixing bacteria in lichens. Isv. Biol. Inst. Permsk. 11: 133-139.

4. Panosyan AK, Nikogosyan VG. 1966. The presence of Azotobacter in lichens. Akad. Nauk. Armian. SSR Biol. Zhurn. Armen. 19: 3-11.

5. Henkel PA, Plotnikova TT. 1973. Nitrogen-fixing bacteria in lichens. Izv. Akad. Nauk SSR Ser. Biol. 1973: 807-813.

6. González I, Ayuso-Sacido A, Anderson A, Genilloud O. 2005. Actinomycetes isolated from lichens: evaluation of their diversity and detection of biosynthetic gene sequences. FEMS Microbiol. Ecol. 54: 401-415.

7. Aschenbrenner IA, Cernava T, Berg G, Grube M. 2016. Understanding microbial multi-species symbioses. Front. Microbiol. 7: 180.

8. Grube M, Cernava T, Soh J, Fuchs S, Aschenbrenner I, 
Lassek C, et al. 2015. Exploring functional contexts of symbiotic sustain within lichen-associated bacteria by comparative omics. ISME J. 9: 412-424.

9. Nampoothiri KM, Nair NR, John RP. 2010. An overview of the recent developments in polylactide (PLA) research. Bioresour. Technol. 101: 8493-8501.

10. Chen G-Q. 2010. Plastics Completely Synthesized by Bacteria: Polyhydroxyalkanoates, pp. 17-37. In Chen G-Q (ed.), Plastics from Bacteria: Natural functions and Applications, vol. 14. Microbiology Monographs, Springer Berlin Heidelberg, Germany.

11. Suriyamongkol P, Weselake R, Narine S, Moloney M, Shah S. 2007. Biotechnological approaches for the production of polyhydroxyalkanoates in microorganisms and plants - a review. Biotechnol. Adv. 25: 148-175.

12. Doi Y, Kitamura S, Abe H. 1995. Microbial synthesis and characterization of poly(3-hydroxybutyrate-co-3-hydroxyhexanoate). Macromolecules 28: 4822-4828.

13. Shahid S, Mosrati R, Ledauphin J, Amiel C, Fontaine P, Gaillard J-L, et al. 2013. Impact of carbon source and variable nitrogen conditions on bacterial biosynthesis of polyhydroxyalkanoates: Evidence of an atypical metabolism in Bacillus megaterium DSM 509. J. Biosci. Bioeng. 116: 302-308.

14. Verlinden R, Hill D, Kenward M, Williams C, Radecka I. 2007 Bacterial synthesis of biodegradable polyhydroxylalkanoates. J. Appl. Microbiol. 102: 1437-1449.

15. Gao X, Yuan XX, Shi ZY, Guo YY, Shen XW, Chen JC, et al. 2012. Production of copolyesters of 3-hydroxybutyrate and medium-chain-length 3-hydroxyalkanoates by E. coli containing an optimized PHA synthase gene. Microb. Cell Fact. 11: 130.

16. Matias F, Brandt CA, da Silva ES, de Andrade Rodrigues MF. 2017. Polyhydroxybutyrate and polyhydroxydodecanoate produced by Burkholderia contaminans IPT 553. J. Appl. Microbiol. 123: 124-133.

17. Mohan SV, Reddy MV. 2013. Optimization of critical factors to enhance polyhydroxyalkanoates (PHA) synthesis by mixed culture using Taguchi design of experimental methodology. Bioresour. Technol. 128: 409-416.

18. Nikodinovic J, Kenny ST, Babu RP, Woods T, Blau WJ, O'Connor KE. 2008. The conversion of BTEX compounds by single and defined mixed cultures to medium-chain-length polyhydroxyalkanoate. Appl. Microbiol. Biotechnol. 80: 665673.

19. Narancic T, Kenny ST, Djokic L, Vasiljevic B, O'Connor KE, Nikodinovic-Runic J. 2012. Medium-chain-length polyhydroxyalkanoate production by newly isolated Pseudomonas sp. TN301 from a wide range of polyaromatic and monoaromatic hydrocarbons. J. Appl. Microbiol. 113: 508-520.

20. Povolo S, Basaglia M, Fontana F, Morelli A, Casella S. 2015. Poly(hydroxyalkanoate) production by Cupriavidus necator from fatty waste can be enhanced by phaZ1 inactivation. Chem. Biochem. Eng. Q 29: 67-74.

21. Filonov AE, Puntus IF, Karpov AV, Kosheleva IA,
Kashparov KI, Slepenkin AV, et al. 2004. Efficiency of naphthalene biodegradation by Pseudomonas putida G7 in soil. J. Chem. Technol. Biotechnol. 79: 562-569.

22. Reddy MV, Mawatari Y, Yajima Y, Seki C, Hoshino T, Chang Y-C. 2015. Poly-3-hydroxybutyrate (PHB) production from alkylphenols, mono and poly-aromatic hydrocarbons using Bacillus sp. CYR1: a new strategy for wealth from waste. Bioresour. Technol. 192: 711-717.

23. Cernava T, Müller H, Aschenbrenner IA, Grube M, Berg G. 2015a. Analysing the antagonistic potential of the lichen microbiome against pathogens by bridging metagenomic with culture studies. Front. Microbiol. 6: 620.

24. Lee YM, Kim EH, Lee HK, Hong SG. 2014. Biodiversity and physiological characteristics of Antarctic and Arctic lichensassociated bacteria. World J. Microbiol. Biotechnol. 30: 27112721.

25. Cernava, T. 2015. Exploring the Substantial Contributions and the Global Interactions of the Microbiome in an Ancient Symbiosis. Doctoral thesis, Graz University of Technology, Graz. 15-16.

26. Eymann C, Lassek C, Wegner U, Bernhardt J, Fritsch OA, Fuchs S, et al. 2017. Symbiotic interplay of fungi, algae, and bacteria within the lung lichen Lobaria pulmonaria L. Hoffm. as assessed by state-of-the-art metaproteomics. J. Proteome Res. 16: 2160-2173.

27. Castro-Sowinski S, Burdman S, Matan O, Okon Y. 2010. Natural functions of bacterial polyhydroxyalkanoates, pp. 39-61. In Chen G-Q (ed.), Plastics from Bacteria: Natural functions and Applications, Microbiology Monographs, Springer, Berlin, Heidelberg.

28. Pham TH, Webb JS, Rehm BH. 2004. The role of polyhydroxyalkanoate biosynthesis by Pseudomonas aeruginosa in rhamnolipid and alginate production as well as stress tolerance and biofilm formation. Microbiology 150: 3405-3413.

29. Goh YS, Tan IKP. 2012. Polyhydroxyalkanoate production by Antarctic soil bacteria isolated from Casey Station and Signy Island. Microbiol. Res. 167: 211-219.

30. Wang Q, Nomura CT. 2010. Monitoring differences in gene expression levels and polyhydroxyalkanoate (PHA) production in Pseudomonas putida KT2440 grown on different carbon sources. J. Biosci. Bioeng. 110: 653-659.

31. Borrero-de Acuña JM, Bielecka A, Häussler S, Schobert M, Jahn M, Wittmann C, et al. 2014. Production of medium chain length polyhydroxyalkanoate in metabolic flux optimized Pseudomonas putida. Microb. Cell Fact. 13: 88.

32. Ostle AG, Holt JG. 1987. Nile blue A as a fluorescent stain for poly- $\beta$-hydroxybutyrate. Appl. Environ. Microbiol. 44: 238241.

33. Oehmen A, Keller-Lehmann B, Zeng RJ, Yuan Z, Keller J. 2005. Optimisation of poly- $\beta$-hydroxyalkanoate analysis using gas chromatography for enhanced biological phosphorus removal systems. J. Chromatogr. A 1070: 131-136.

34. Dib MA, Bendahou M, Bandiabdellah A, Djabou N, Allali 
A, Tabti B, et al. 2010. Partial chemical composition and antimicrobial activity of Daucus crinitus Desf. extracts. Grasas Y Aceites 61: 271-278.

35. Lin W, Wang Y, Gorby Y, Nealson K, Pan Y. 2013. Integrating niche-based process and spatial process in biogeography of magnetotactic bacteria. Sci. Rep. 3: 1643.

36. Kim OS, Cho YJ, Lee K, Yoon $\mathrm{SH}$, Kim M, Na H, et al. 2012. Introducing EzTaxon-e: a prokaryotic 16S rRNA gene sequence database with phylotypes that represent uncultured species. Int. J. Syst. Evol. Microbiol. 62: 716-721.

37. Thompson JD, Gibson TJ, Plewniak F, Jeanmougin F, Higgins DG. 1997. The CLUSTAL_X windows interface: flexible strategies for multiple sequence alignment aided by quality analysis tools. Nucleic. Acids Res. 25: 4876-4882.

38. Saitou N, Nei M. 1987. The neighbor-joining method: a new method for reconstructing phylogenetic trees. Mol. Biol. Evol. 4: 406-425.

39. Kumar S, Stecher G, Tamura K. 2016. MEGA7: molecular evolutionary genetics analysis version 7.0 for bigger datasets. Mol. Biol. Evol. 33: 1870-1874.

40. Solaiman DKY, Ashby RD, Foglia TA. 2000. Rapid and specific identification of medium-chain-length polyhydroxyalkanoate synthase gene by polymerase chain reaction. Appl. Microbiol. Biotechnol. 53: 690-694.

41. Livak KJ, Schmittgen TD. 2001. Analysis of relative gene expression data using real-time quantitative PCR and the 2- $\Delta \Delta$ CT method. Methods 25: 402-408.

42. Chaudhry WN, Jamil N, Ali I, Ayaz MH, Hasnain S. 2011. Screening for polyhydroxyalkanoate (PHA)-producing bacterial strains and comparison of PHA production from various inexpensive carbon sources. Ann. Microbiol. 61: 623-629.

43. Selbmann L, Zucconi L, Ruisi S, Grube M, Cardinale M, Onofri S. 2010. Culturable bacteria associated with Antarctic lichens: affiliation and psychrotolerance. Polar Biol. 33: 71-83.

44. Cernava T, Aschenbrenner IA, Grube M, Liebminger S, Berg G. 2015. A novel assay for the detection of bioactive volatiles evaluated by screening of lichen-associated bacteria. Front. Microbiol. 6: 398.

45. Honegger R, Edwards D, Axe L. 2013. The earliest records of internally stratified cyanobacterial and algal lichens from the Lower Devonian of the Welsh Borderland. New Phytol. 197: 264-275.

46. Ramsay BA, Saracovan I, Ramsay JA, Marchessault RH. 1992. Effect of nitrogen limitation on long-side-chain polybeta-hydroxyalkanoate synthesis by Pseudomonas resinovorans. Appl. Environ. Microbiol. 58: 744-746.

47. Hoffmann N, Rehm BHA. 2005. Nitrogen-dependent regulation of medium-chain length polyhydroxyalkanoate biosynthesis genes in pseudomonads. Biotechnol. Lett. 27: 279-282.

48. Thakor NS, Patel MA, Trivedi UB, Patel KC. 2003. Production of poly( $\beta$-hydroxybutyrate) by Comamonas testosteroni during growth on naphthalene. World J. Microbiol.
Biotechnol. 19: 185-189.

49. Leneva NA, Kolomytseva MP, Baskunov BP, Golovleva LA. 2010. Enzymes of Naphthalene Metabolism by Pseudomonas fluorescens 26K Strain. Biochemistry (Moscow) 75: 562-570.

50. Panda B, Jain P, Sharma L, Mallick N. 2006. Optimization of cultural and nutritional conditions for accumulation of poly$\beta$-hydroxybutyrate in Synechocystis sp. PCC 6803. Bioresour. Technol. 97: 1296-1301.

51. Ward PG, Goff M, Donner M, Kaminsky W, O'Connor K. 2006. A two step chemo-biotechnological conversion of polystyrene to a biodegradable plastic. Environ. Sci. Technol. 40: 2433-2437.

52. Tan GYA, Chen CL, Ge L, Li L, Tan SN, Wang JY. 2015. Bioconversion of styrene to poly(hydroxyalkanoate) (PHA) by the new bacterial strain Pseudomonas putida NBUS12. Microbes Environ. 30: 76-85.

53. Chung AL, Jin HL, Huang LJ, Ye HM, Chen JC, Wu Q, et al. 2011. Biosynthesis and characterization of poly (3-hydroxydodecanoate) by $\beta$-oxidation inhibited mutant of Pseudomonas entomophila L48. Biomacromolecules 12: 3559-3566.

54. Elbahloul Y, Steinbüchel A. 2009. Large-scale production of poly(3-hydroxyoctanoic acid) by Pseudomonas putida GPo1 and a simplified downstream process. Appl. Environ. Microbiol. 75: 643-651.

55. Gao J, Ramsay JA, Ramsay BA. 2016. Fed-batch production of poly-3- hydroxydecanoate from decanoic acid. J. Biotechnol. 218: 102-107.

56. Reddy MV, Yajima Y, Mawatari Y, Hoshino T, Chang YC. 2015b. Degradation and conversion of toxic compounds into useful bioplastics by Cupriavidus sp. CY-1: relative expression of the PhaC gene under phenol and nitrogen stress. Green Chem. 17: 4560-4569.

57. Follonier S, Henes B, Panke S, Zinn M. 2012. Putting cells under pressure: a simple and efficient way to enhance the productivity of medium-chain-length polyhydroxyalkanoate in processes with Pseudomonas putida KT2440. Biotechnol. Bioeng. 109: 451-461.

58. Le Meur S, Zinn M, Egli T, Thöny-Meyer L, Ren Q. 2012. Production of medium-chain-length polyhydroxyalkanoates by sequential feeding of xylose and octanoic acid in engineered Pseudomonas putida KT2440. BMC Biotechnol. 12: 53.

59. Kaur G, Roy I. 2015. Strategies for large-scale production of polyhydroxyalkanoates. Chem. Biochem. Eng. Q. 29: 157-172.

60. Oksanen I. 2006. Ecological and biotechnological aspects of lichens. Appl. Microbiol. Biotechnol. 73: 723-734.

61. Hoffmann N, Steinbuchel A, Rehm BHA. 2000. Homologous functional expression of cryptic phaG from Pseudomonas oleovorans establishes the transacylasemediated polyhydroxyalkanoate biosynthetic pathway. Appl. Microbiol. Biotechnol. 54: 665-670.

62. Popp N, Schlömann M, Mau M. 2006. Bacterial diversity in the active stage of a bioremediation system for mineral oil hydrocarbon-contaminated soils. Microbiology 152: 3291-3304. 
63. Kenny ST, Nikodinovic-Runic J, Kaminsky W, Woods T, Babu RP, Keely CM, et al. 2008. Up-cycling of PET (polyethylene terephthalate) to the biodegradable plastic PHA (polyhydroxyalkanoate). Environ. Sci. Technol. 42: 76967701.

64. Feijoo-Siota L, Rosa-Dos-Santos F, de Miguel T, Villa TG. 2008. Biodegradation of naphthalene by Pseudomonas stutzeri in marine environments: Testing cells entrapment in calcium alginate for use in water detoxification. Bioremediat. J. 12: 185-192.

65. Karimi B, Habibi M, Esvand M. 2015. Biodegradation of naphthalene using Pseudomonas aeruginosa by up flow anoxic-aerobic continuous flow combined bioreactor. J. Environ. Health. Sci. Eng. 13: 26.

66. Jacques RJS, Santos EC, Bento FM, Peralba MCR, Selbach PA, Sá ELS, et al. 2005. Anthracene biodegradation by Pseudomonas $\mathrm{sp}$. isolated from a petrochemical sludge land farming site. Int. Biodeter. Biodegr. 56: 143-150.
67. Huisman GW, Wonink E, Meima R, Kazemier B, Terpstra P, Witholt B. 1991. Metabolism of poly(3-hydroxyalkanoates) (PHAs) by Pseudomonas oleovorans. Identification and sequences of genes and function of the encoded proteins in the synthesis and degradation of PHA. J. Biol. Chem. 5: 21912198.

68. Ciesielski S, Cydzik-Kwiatkowska A, Pokoj T, Klimiuk E. 2006. Molecular detection and diversity of medium-chainlength polyhydroxyalkanoates-producing bacteria enriched from activated sludge. J. Appl. Microbiol. 101: 190-199.

69. McCool GJ, Cannon MC. 2001. PhaC and PhaR are required for polyhydroxyalkanoic acid synthase activity in Bacillus megaterium. J. Bacteriol.183: 4235-4243.

70. Catone MV, Ruiz JA, Castellanos M, Segura D, Espin G, López NI. 2014. High polyhydroxybutyrate production in Pseudomonas extremaustralis is associated with differential expression of horizontally acquired and core genome polyhydroxyalkanoate synthase genes. PLoS One 9: e98873. 